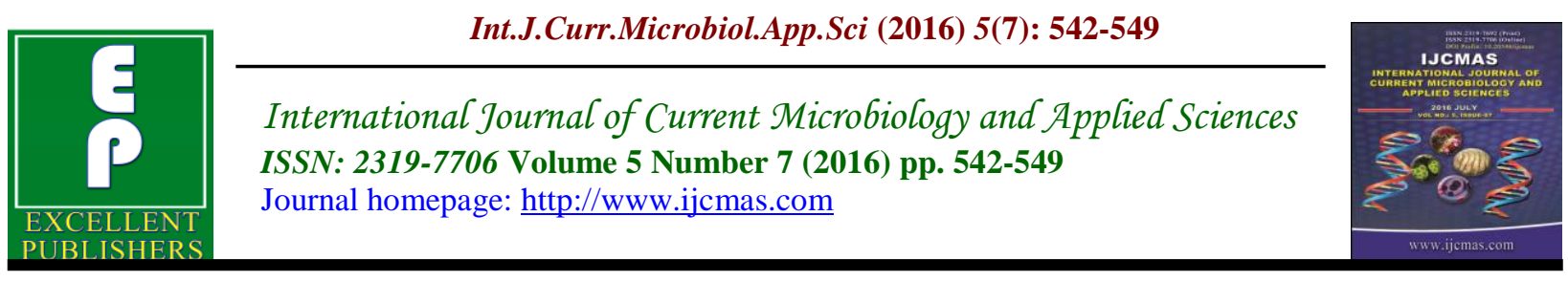

Original Research Article

http://dx.doi.org/10.20546/ijcmas.2016.507.059

\title{
Screening of Antimicrobial Potential of Barleria prionitis Linn Aerial Parts against Common Respiratory Tract Pathogens
}

\author{
Ajeet Singh*, Vinay Mohan Pathak and Navneet \\ Department of Botany and Microbiology Gurukul Kangri University, \\ Haridwar, Uttrakhand India \\ *Corresponding author
}

\begin{abstract}
A B S T R A C T
Keywords

Respiratory tract pathogens, antibacterial, antifungal, MIC, Barleria prionitis.

\section{Article Info}

Accepted:

15 June 2016

Available Online:

10 July 2016

The antimicrobial potential of Barleria prionitis Linn. (Aerial parts) were evaluated against common respiratory tract infections causing bacterial and fungal pathogens. The pathogens used in this study were Streptococcus pneumoniae (MTCC 655), Staphylococcus aureus (MTCC 1144), Pseudomonas aeruginosa (MTCC 2474), Streptococcus pyogens (MTCC 442), Haemophillus influenzae (MTCC 3826) and two fungal strains Candida albicans (MTCC 227), Aspergillus niger (MTCC 921). Antibacterial and antifungal activities were determined by Agar well diffusion method, poison food technique, respectively. Erythromycin and fuconazole were used as positive control to establish the sensitivity of bacterial and fungal strains respectively. Methanol $(\mathrm{MeOH})$ extract was found most active followed by ACE, $\mathrm{H}_{2} \mathrm{O}$ and PET respectively. The maximum inhibition zone was found against $S$. pneumoniae $(19.40 \pm 0.64 \mathrm{~mm})$ followed by $S$. aureus $(18.73 \pm 0.80 \mathrm{~mm}), P$. aeruginosa $(14.98 \pm 0.28 \mathrm{~mm}), \quad S$. pyogens $(14.2 \pm 0.47 \mathrm{~mm}), H$. influenzae $(10.11 \pm 0.21 \mathrm{~mm})$, and Candia albicans $(6.66 \pm 32 \mathrm{~mm})$. Minimum inhibitory concentrations (MICs) were observed for $\mathrm{MeOH}$ extract between 3.12 to $25 \mathrm{mg} / \mathrm{mL}$ against $S$. pneumoniae, $S$. pyogens and Candida albicans respectively. The antimicrobial activity of the crude extracts of plant represents a significant outcome for the treatment of respiratory diseases.
\end{abstract}

\section{Introduction}

Plants are the backbone of all life on the earth and a necessary resource for human wellbeing as raw medicine, food and fuel. Traditional plant derived medicines have been used in most parts of the world and their use in combating microbial disease is becoming the focus of several studies (Bhavnani and Ballow, 2000; Chariandy et al., 1999). Plant derived substances have recently become of great interest owing to their resourceful applications.
It has been estimated that 14- $28 \%$ of higher plant species are used in the medicinal purposes and that $74 \%$ of pharmacologically active phytochemicals components were discovered after following up on ethno medicinal use of the plants (Borah et al., 2012). In the last couple of decade, a new development in the research and promotion of plants based drugs has become increasingly towards the herbal medicines (Bisset, 1994; Tyler, 1997). 
Respiratory tract infections are the most common ailment including allergies, asthma and chronic obstructive pulmonary disease (COPD). The climatic conditions are very favourable for spread of such diseases commonly transmitted by coughing and sneezing (airborne disease). Some common causative agents are Escherichia coli, Klebsilla pneumoniae responsible for nosocomial infections (Saonuam et al., 2008), Haemophilus influenzae, Streptococcus pneumoniae, Streptococcus pyogenes and Moraxella catarrhalis for community acquired infections, Enterobacter cloacae and Bacillus subtilis which cause occupational asthma, respectively (Kayser et al., 1990; ChanYenug and Lam, 1986). In 2002, due to the respiratory tract infections there were 3.9 million deaths reported worldwide and $6.91 \%$ of all deaths that year (Beaglehole et al., 2004).

Barleria prionitis Linn (Acanthaceae) is distributed throughout Africa, India, Sri Lanka and tropical Asia. The height of the plant is about 1.5 metres. B. prionitis is a shrub and flowers are yellow in colour. Flowering occurs during August - October (Kirtikar and Basu, 1999; Kaushik and Dhiman, 2000). In ayurveda it is known by various names like kuranta, kurantaka, kuranda, kurandaka, sahachara, shairiya. In folk medicine it is popularly known as piyaabaaaa, jhinti and ketsariyaa. It is known as 'Vajradanti because of its anti dontalgic property (Khare, 2007; Banerjee et al., 2012).

The whole plant, root, leaves and bark of the $B$. prionitis reside in a significant place in the indigenous system of medicine in India for controlling the different types of ailments such as inflammations, swellings, boils, glandular etc. (Khare, 2004; Daniel, 2006; Aneja et al., 2010). The decoction of aerial parts of $B$. prionitis is used in whooping cough, anti-respiratory synctyial virus, antiarthritic, anti-inflammatory and antifertility activities. The antibacterial activity of $B$. prionitis leaf extracts were showed against $S$. typhi, $V$. cholerae, $M$. luteus, L. sporogens, Citrobacter, B. subtils, B. cereus, and Providencia (Paul and Saha, 2012). The $\mathrm{MeOH}$ extract of root leaves and stems showed potent antioxidant activity. Ethanolic extract of whole plant extract of $B$. prionitis showed considerable antioxidant prosperities (Kapoor et al., 2014; Sharma et al., 2014: Chetan et al., 2010). Preliminary phytochemical screening of hydro-methanol (70\%) extract of $B$. prionitis whole plant revealed the occurrence of saponins, glycosides, tannins and flavonoids (Maji et al., 2011). The leaves and flowering tops of $B$. prionitis showed high amount of potassium salts (Khare, 2007).

\section{Materials and Methods}

\section{Collection and preparation of plant material}

The plant material (aerial parts) was collected from the botany garden of the campus, Gurukul Kangri University Haridwar UK (India) during the first week of October, 2013. Collected plant material was washed with tap water and dried under shade at room temperature and crushed into powder using electric grinder.

\section{Extract preparation}

Plant extracts were prepared by immersing $100 \mathrm{~g}$ of powdered plant material in $300 \mathrm{~mL}$ with four different organic solvents i.e. petroleum ether (PET), acetone (ACE), methanol $(\mathrm{MeOH})$ and distilled water $\left(\mathrm{H}_{2} \mathrm{O}\right)$. Powdery material was loaded in Soxhlet apparatus and extracted for $72 \mathrm{~h}$ by successive method (Ahmed et al., 1998). 
Each extract was filtered through Whatman No. 1filter paper. Each extract were evaporated with the help of vacuum evaporator at $30^{\circ} \mathrm{C}$. The dried extracts obtained from vacuum evaporator were exposed to Ultra Violet rays for $24 \mathrm{~h}$ and checked for sterility on nutrient agar plates. Extracts were stored in a refrigerator at $4^{\circ} \mathrm{C}$ for further analysis (Aneja et al., 2010).

\section{Test Microorganisms}

Upper respiratory tract infections causing pathogens were selected for this study. Clinical bacterial strains of gram positive and gram negative bacteria were Streptococcus pyogenes (MTCC 442), Streptococcus pneumoniae (MTCC 655), Staphylococcus aureus (MTCC 1144), Pseudomonas aeroginosa (MTCC 2474), Haemophillus influenzae (MTCC 3826). Two fungal strains Candida albicans (MTCC 227), Aspergillus niger (MTCC 921) were also selected and all pathogens procured from Institute of Microbial Technology (IMTECH), Chandigarh (India).

\section{Antibacterial Activity}

\section{Preparation of Stock Cultures}

Stock cultures of bacterial and fungal were maintained at $4{ }^{\circ} \mathrm{C}$ on slopes of nutrient agar medium. Active cultures for experiments were prepared by transferring microbial inoculums from stock cultures to test tubes containing Mueller-Hinton Broth (MHB) for bacteria that were incubated at $37^{\circ} \mathrm{C}$ for $24 \mathrm{~h}$ in BOD incubator. Antibacterial activity was tested by agar well- diffusion method (Gautam et al., 2012). $100 \mu \mathrm{l}$ of diluted inoculums of $10^{5} \mathrm{CFU} \mathrm{mL}{ }^{-1}$ (IP, 1996) of 24 $\mathrm{h}$ old cultures of test organisms were mixed in Mueller Hinton Agar (MHA) medium and shaken. Medium was poured in sterilized Petri plates. Plates were allowed to solidify for $5-10 \mathrm{~min}$. A sterile cork borer of $6 \mathrm{~mm}$ diameter was used to punch wells in medium and filled with $45 \mu \mathrm{L}$ of $200 \mathrm{mg}$ $\mathrm{mL}{ }^{-1}$ final concentration of extracts. DMSO (dimethyl sulphoxide) was used as negative control. All extracts were assayed in triplicate and the mean values were noted. The plates were incubated at $37^{\circ} \mathrm{C}$ for $24 \mathrm{~h}$ in BOD incubator. The antibacterial activity was interpreted from the size of the diameter of inhibition zone measured in millimetre $(\mathrm{mm})$ as experiential from clear zones nearby the wells. This method depends upon the diffusion of the tested material to such an extent that growth of the added microorganisms is prevented completely in a zone around the hole containing a solution of tested material (Prabhat et al., 2005).

\section{Minimum inhibitory concentrations (MICs)}

MIC was done using two fold serial dilution method adapted by (Aboaba et al., 2006; Ajaeoba et al., 2003). Sterilized nutrient broth was poured uniformly into all test tubes. Mcfarland's turbidity standard scale number 0.5 was prepared to provide a turbid solution. Saline solution was inoculated with each of the test organism and incubated for 6 $\mathrm{h}$ at $37^{\circ} \mathrm{C}$ to prepare a turbid suspension of the tested microbes. After incubation, dilution of the culture in DMSO was prepared until it matched with the turbidity $\left(1.5 \times 10^{6} \mathrm{cfu} / \mathrm{mL}\right)$ of the Mcfarland scale. A solution of $\mathrm{MeOH}$ extract was serially diluted with broth to obtain the following concentrations $100 \mathrm{mg} / \mathrm{mL}, 50 \mathrm{mg} / \mathrm{mL}, 25$ $\mathrm{mg} / \mathrm{mL}, 12.5 \mathrm{mg} / \mathrm{mL}, 6.25 \mathrm{mg} / \mathrm{mL}, 3.12$ $\mathrm{mg} / \mathrm{mL}$ and $1.56 \mathrm{mg} / \mathrm{mL}$. From the above suspension prepared in DMSO, $0.1 \mathrm{~mL}$ was dispensed into the different concentration of the extract in nutrient broth. All test tubes were observed for turbidity after incubating at $37^{\circ} \mathrm{C}$ for $24 \mathrm{~h}$. The test tube with the concentration at which no detectable growth was observed determined the MIC. 


\section{Antifungal activity}

The antifungal potential of aerial parts extracts were determined by poisoned food (Grover and Moore, 1962; Nene and Thapliyal, 2002; Pal and Kumar, 2013; Pal et al., 2013). An aliquot of $250 \mathrm{mg} / \mathrm{ml}$ concentration of different extracts were poured into Petri dishes and followed by adding $19 \mathrm{~mL}$ of melted Sabouraud dextrose agar (SDA) medium. $6 \mathrm{~mm}$ mycelial disc was punched with a sterile cork borer from the borders of two to three days old culture of $A$. niger and placed the disc in the centre of agar plate. Percentage inhibition zone of mycelial growth was determined by measuring the relative growth of the fungus in the treatment and control by applying the following formula.

$\mathrm{I}=(\mathrm{C}-\mathrm{T}) / \mathrm{C} \times 100$

Where I is the percentage inhibition, $\mathrm{C}$ mean growth rate of the control and $\mathrm{T}$ for the treatment. Extract is not used in the control and fuconazole was used as the reference drug for comparison. All plates were incubated for $48-72 \mathrm{~h}$ at $25^{\circ} \mathrm{C}$ in BOD incubator. All samples were assayed in triplicate and mean values were observed.

\section{Result and Discussion}

Antimicrobial activities of $\mathrm{MeOH}, \mathrm{ACE}$, $\mathrm{H}_{2} \mathrm{O}$ and PET aerial parts extracts of $B$. prionitis are presented in Table no1. $\mathrm{MeOH}$ extract showed the highest antibacterial activity among all solvents followed by ACE, $\mathrm{H}_{2} \mathrm{O}$, and PET. Maximum inhibition zone was found against $S$. pneumoniae $(19.40 \pm 0.64 \mathrm{~mm})$ followed by $S$. aureus $(18.73 \pm 0.80 \mathrm{~mm}), \quad P$. aeruginosa (14.98 $\pm 0.28 \mathrm{~mm}), \quad S$. pyogens $(14.2 \pm 0.47$ $\mathrm{mm}) H$. influenzae $(13.24 \pm 0.80 \mathrm{~mm})$ and $C$. albicans $(8.89 \pm 0.58 \mathrm{~mm})$. Different solvent extracts of barks, leaves and stems of $B$. prionitis showed the good antibacterial potential against $S$. aureus, $P$. aeruginosa, $B$. cereus, and $S$. mutans. It was also reported that among the extracts, $\mathrm{MeOH}$ bark extract showed potential antibacterial activity against all the pathogens. Crude $\mathrm{MeOH}$ extract revealed good antibacterial activity against MDR E. coli with $12 \mathrm{~mm}$ of inhibition zone (Aneja et al., 2010; Khobragade and Bhande, 2012). Chetan et al., 2010 were reported the antibacterial activity of ethanolic leaf extract of $B$. prionitis against $S$. aureus, B. subtilis, $P$. vulgaris, $K$. pneumoniae, $E$. coli and $P$. aeruginosa. Antibacterial activity of four extracts i.e. $\mathrm{H}_{2} \mathrm{O}, \mathrm{PET}, \mathrm{CHCl}_{3}$ and $\mathrm{ACE}$ were reported against $L$. rhamnosus (MTCC1408), S. mutans (MTCC 890), S. aureus MTCC 3408), A. viscoscus (MTCC 7345), S. epidermidis (MTCC 3639), E. coli (MTCC 732) and B. subtilis (MTCC 3160). Pronounced inhibition of the four extracts was observed for bacterial species, $L$. rhamnosus $\mathrm{CHCl}_{3}$ extract was found to be more effective against the entire test microorganism (Diwan et al., 2012). In vitro propagated shoot tips and leaves of $B$. prionitis with ethanol, ether and chloroform extracts showed the antibacterial activity (Shukla et al., 2011). Antibacterial activities of $B$. prionitis bark and leaf $\mathrm{MeOH}$ extracts against $B$. cereus $(22.66 \mathrm{~mm})$ followed by PET leaf extract against E. coli $(21.66 \mathrm{~mm})$. Minimum inhibition was showed by PET leaf extract against $A$. faecalis $(4.66 \mathrm{~mm})$ followed by $\mathrm{MeOH}$ bark extract against $A$. faecalis (5.33 mm) (Kumar et al., 2013).

The antifungal potential of $B$. prionitis Linn. of all extracts were measured in $\%$ inhibition that is presented in table 2. Maximum \% of inhibition was observed by the standard drug (74.31\%), fuconazole followed by $\mathrm{H}_{2} \mathrm{O}$ (35.11\%), ACE (35.02\%), MeOH (24.51\%), and PET (20.18\%), respectively. 
Table.1 Diameter of inhibition zone all extracts of B. prionitis

\begin{tabular}{|c|c|c|c|c|c|}
\hline \multirow[t]{2}{*}{ Pathogen } & \multicolumn{4}{|c|}{ Inhibition zone ( $\mathrm{mm}$ in diameter) } & \multirow{2}{*}{$\begin{array}{c}\text { Positive } \\
\text { control } \\
\text { Erythromycin }\end{array}$} \\
\hline & PET & ACE & МeOH & $\mathrm{H}_{2} \mathrm{O}$ & \\
\hline S. pneumoniae & $13.33 \pm 0.57$ & $14.22 \pm 0.36$ & $19.40 \pm 0.64$ & $17.34 \pm 0.70$ & $27.56 \pm 0.95$ \\
\hline S. aureus & $12.88 \pm 0.22$ & $18.73 \pm 0.80$ & $15 \pm 0.45$ & $14.22 \pm 0.62$ & $29.42 \pm 0.73$ \\
\hline H. influenzae & $10.11 \pm 0.21$ & $11.74 \pm 0.22$ & $13.24 \pm 0.80$ & $10.39 \pm 0.21$ & $21.68 \pm 0.43$ \\
\hline P. aeruginosa & $12.63 \pm 0.91$ & $11.54 \pm 0.62$ & $14.98 \pm 0.28$ & $12.71 \pm 0.41$ & $16.91 \pm 0.49$ \\
\hline S.pyogenes & $10.93 \pm 0.69$ & $13.80 \pm 0.25$ & $14.2 \pm 0.47$ & $14.04 \pm 0.33$ & $25.01 \pm 0.57$ \\
\hline C. albicans & $6.66 \pm 32$ & $7.34 \pm 0.51$ & $7.55 \pm 46$ & $8.89 \pm 0.58$ & $22.55 \pm 0.56$ \\
\hline
\end{tabular}

cork borer diameter $(6 \mathrm{~mm})$, all values were mean of three replicates with standard error , PET $=$ Petroleum ether, $\mathrm{ACE}=$ Acetone, $\mathrm{MeOH}=$ Methanol, $\mathrm{H}_{2} \mathrm{O}=$ Aqueous

Table.2 Effect of aerial parts extract and fuconazole on the mycelial growth rate of Aspergillus niger

\begin{tabular}{|c|c|c|c|}
\hline Fungicide/extract & $\begin{array}{c}\text { Mycelial growth } \\
(\mathbf{m m})\end{array}$ & Control & \% inhibition \\
\hline PET & $30.44 \pm 0.58$ & $38.14 \pm 0.28$ & 20.18 \\
\hline ACE & $23.3 \pm 0.28$ & $35.86 \pm .54$ & 35.02 \\
\hline MeOH & $28.6 \pm 0.76$ & $37.89 \pm 0.45$ & 24.51 \\
\hline $\mathbf{H}_{\mathbf{2}} \mathbf{O}$ & $21.56 \pm 0.54$ & $33.23 \pm 0.76$ & 35.11 \\
\hline Fuconazole & $9.44 \pm 56$ & $36.76 \pm 34$ & 74.31 \\
\hline
\end{tabular}

cork borer diameter $6 \mathrm{~mm}$, all values were mean \pm standard error, all values of three replicates

Fig.1 Minimum inhibitory concentrations (MICs) of MeOH extract of B. prionitis Linn. The minimum inhibition is observed at $3.12 \mathrm{mg} / \mathrm{mL}$ for $S$. pneumoniae, S. pyogens, $6.25 \mathrm{mg} / \mathrm{mL}$ for $S$. aureus, $P$. aeruginosa, $12.5 \mathrm{mg} / \mathrm{mL}$ for $H$. influenzae and $25 \mathrm{mg} / \mathrm{mL}$ against $C$. albicans.

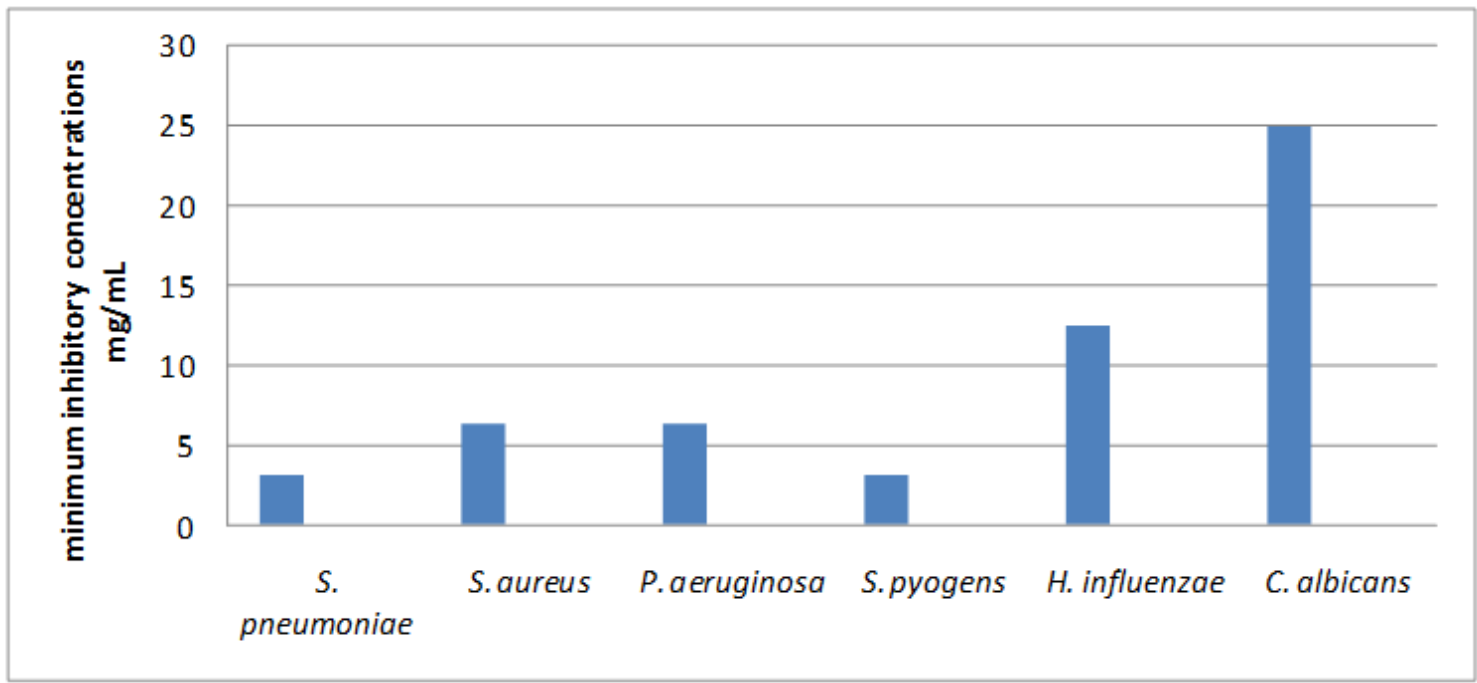


The antifungal activity of ACE, EtOH and $\mathrm{MeOH}$ bark extracts of $B$. prionitis against $S$. cerevisiae, C. albicans and $\mathrm{MeOH}$ extract was found more active against all the fugal strains (Shukla et al., 2011; Aneja et al., 2010). Antifungal activity of $B$. prionitis were reported against $C$. neoformans, $C$. albicans, $C$. vaginitis, $B$. dermatidis using chloroform, acetonitrate and ethanol extract of stem, leaves and roots (Panchal and Singh, 2015).

PET, dichlomethane and ethanol stem and root extracts of $B$. prionitis showed fungistatic and fungicidal properties against C. albicans (Banerjee et al., 2012).

MICs of MeOH extract of B. prionitis Linn. are presented in fig. 1. Minimum inhibitory concentrations (MIC) of $\mathrm{MeOH}$ extract of $B$. prionitis Linn. was observed at $3.12 \mathrm{mg} / \mathrm{mL}$ for $S$. pneumoniae and $S$. pyogens, 6.25 $\mathrm{mg} / \mathrm{mL}$ for $S$. aureus and $P$. aeruginosa, $12.5 \mathrm{mg} / \mathrm{mL}$ for $H$. influenzae and $25 \mathrm{mg} / \mathrm{mL}$ against $C$. albicans.

In conclusion, present study concluded that the aerial parts of $B$. prionitis Linn. have the potent antimicrobial activity against some respiratory bacterial and fungal strains. The $\mathrm{MeOH}$ extract was found most potent in comparison to other solvents. The antimicrobial activity of crude extracts represents a considerable outcome for the treatment of respiratory diseases.

\section{Acknowledgments}

The authors are sincerely thankful to the University Grant Commission- Basic Scientific Research (UGC - BSR), New Delhi for financial support. Authors are also thankful to Head of The Department Botany and Microbiology Gurukul Kangri Univ., Haridwar (India) for providing Lab facilities.

\section{References}

Aboaba, O.O., Smith S.I., Olide F.O. 2006. Antimicrobial effect of edible plant extract on Escherichia coli 0157:H7. Pak. J. Nutr., 5(4): 325-327.

Ahmed, I., Mehmood, Z., Mohammad, F., 1998. Screening of some Indian medicinal plants for their antimicrobial properties. J. Ethonopharmacol., 62: 183-193.

Ajaieoba, E.O., Onocha P.A., Nawozo, S.O., Sama, W. 2003. Antimicrobial and cytotoxicity evaluation of Bucholzia coriancea stem bark. Filoterapia, 74: 706-709.

Aneja, K.R., Joshi, R,. Sharma, C. 2010. Potency of Barleria prionitis L. Bark extracts against oral diseases causing strains of bacteria and fungi of clinical origin. New York Sci. J., 3: 5-12.

Banerjee, A.K., Maji, S., Mahapatra, S. and Banjeri, P. Barleria prionitis Linn.: A review of itsTtraditional uses, Phytochemistry, Pharmacology and Toxicity, Res. J. Phytochem., 6: 31-41.

Baroh, M., Ahmed, S., Das, S. 2012. A comparative study of the antibacterial activity of the ethanolic extracts of Vitex negunda L., Fragaria vesca L., Terminalia arjuna and Citrus maxima. Asian J. Pharmaceutical and Biol. Res., 2(3): 183-187.

Beaglehole, R. 2004. The World Health Report 2004 - Changing History. World Health Organization. 120-124.

Bhavnani, S.M., Ballow, C.H., 2000. New agents for Gram-positive bacteria. Curr. Opin. Microbiol., 3: 528-534.

Bisset, N.G. 1994. Herbal Drugs and Phytopharmaceuticals. CRC Press, Boca Raton.

Chan-Yenug, M., Lam, S. 1986. Occupational asthma. Am Rev. Respir. Dis., 133: S686-703. 
Chariandy, C.M., Seaforth, C.E., Phelps, R. H., 1999. Screening of medicinal plants from Trinidad and Tobago for antimicrobial and insecticidal properties. J. Ethnopharmacol., 64: 265-270.

Chetan, C., Suraj, M., Maheshwari, C., Rahul, A., Priyanka, P. 2011. "Screening of antioxidant activity and total phenolic content of whole plant of Barleria prionitis." Linn. Int. J. Res. Ayurveda Pharma., 2: 1313-1319.

Daniel, M. 2006. Medicinal plants: chemistry and properties. $1^{\text {st }}$ Edn., Science Publishers, USA.,78.

Diwan, P.D., Gadhikar, Y.A. 2012. Assessment of Phytochemical Composition and Antibacterial Activity of different extracts of Barleria prionitis leaves against Oral Microflora to Improve Dental Hygiene. Asian J. Pharmaceutical and Clin. Res., 5(2): 182-184.

Gautam, S.S., Navneet, Kumar, S. 2012. The antibacterial and phytochemical aspects of Viola odorata Linn. Extracts against respiratory tract pathogens. Proc. Natl. Acad. Sci., India B Biol. Sci., 82(4): 567-572.

Grover, R.K., Moore, J.D. 1962. Toximetric studies of fungicides against brown rot organisms, Sclerotia fructicola and S. laxa. Phytopathol., 52: 876-880.

IP. 1996. Indian Pharmacopeia. Vol. 2, CSIR, Ministry of health, India. A $100-107$.

Kapoor, A., Shukla, S., Kaur, R., and Kumar, R., 2014. Preliminary phytochemical screening and antioxidant activity of whole plant of Barleria prionitis linn. Int. J. Adv. Pharmacy, Biol. Chem., vol.3 (2), 410419.

Kaushik, P., Dhiman, A.K. 2000. Medicinal Plants and Raw Drugs of India. Bishen
Singh Mahendra Pal Singh, Shiva Offset press. Dehradun, India. 412.

Kayser, F.H., Morenzoni, G., Santanam, P. 1990. The second European collaborative study on the frequency of antimicrobial resistance in Haemophilus influenzae. Eur. J. Clin. Microbiol. Infect. Dis., 9: 810-817.

Khare, C.P. 2004. Indian Herbal Remedies: Rational Western Therapy, Ayurvedic and Other Traditional Usage, Botany. $1^{\text {st }}$ Edn., Springer, New York, 93-94.

Khare, C.P. 2007. Indian medicinal plants: an illustrated dictionary. $1^{\text {st }}$ Edn., Springer science, New York, 82-83.

Khobragade, C.N., Bhande, R.M. 2012. In vitro antibacterial, membrane damage, antioxidant and anti-inflammatory activities of Barleria prionitis Linn. extract on UTI causing multidrug resistant E. coli. Int. J. Curr. Pharmaceutical Res., Vol 4, (1): 6469.

Kirtikar，K.R., Basu， B.D. 1999. Indian Medicinal Plants. Bishen Singh Mahendra Pal Singh, New Connaught Place, Dehradun. 1877-1878.

Kumar, U., Ahmed, F., Khanojia, P, Kukreja, K., Kumari, S. and Bhat, R.A. 2013. Exploration of Antioxidant and Antibacterial Activity of Barleria prionitis Linn. Int. J. Curr. Microbiol. App. Sci., 2(12): 585-591.

Maji, A.K., Mahapatra, S., Banerji, P. and Banerjee, D. 2011. Mast cell stabilization and membrane protection activity of Barleria prionitis L. Pharmacog. J., 3: 67-71.

Nene, Y, Thapilyal, L. 2002. Poisoned food technique of fungicides in plant disease control ( $3^{\text {rd }}$ Ed.) Oxford and IBH Publishing Company, New Delhi.

Pal, G.K., and Kumar, B. 2013. Antifungal activity of some common weed extracts against wilt causing fungi, 
Fusarium oxysporum, Curr. Discovery, 2(1): 62-67.

Pal, G.K., Kumar, B. and Shahi, S.K. 2013. Antifungal activity of some common weed extracts against seedborne phytopathogenic fungi Alternaria spp. Int. J. Universal Pharmacy and Life Sci., 3(2): 6-14.

Panchal, P. and Singh, K. 2015. Antimicrobial activity of Barleria prionitis on pathogenic strains. 7(4).73-75.

Paul, S., Saha, D. 2012. Comparative study of the efficiency of Barleria prionitis leaf extracts against bacteria. Asian J. Pharmaceutical Res., 2(3): 107-110.

Prabhat, Navneet and S. Krishna. 2005. Antibacterial activity of apamarga Achyranthes aspera Linn. Nat. Acad. Sci. Lett. 28: 379 - 381.

Saonuam, P., Hiransuthikul, N., Suankratay, C., Malathum, K., Danchaivijitr, S.,
2008. Risk factors for nosocomial infections caused by extended spectrum $\beta$-lacamase producing Escherichia coli or Klebsiela pneumoniae in Thailand. Asian Biomed., 2: 485-491.

Sharma, P., Sharma, G.N., Srivastava, B., and Jadhav, H.R., 2014. Evaluation of antioxidant potential of Barleria prionits leaf and stem. American J. Phytomedicine and Clin. Therapeutics, 2(11): 1177-1186.

Shukla, P., Singh A., Gawri, S., Alexander, A., and Sonwane, S. 2011. In vitro propagation of Barleria prionitis Linn. and its antibacterial activity. Int. J. Pharma Professional's Res., vol. 2(1). 198-200.

Tyler, V.E. 1997. The Herbal Remedies Market. Chem. Tech., 27: 52-57.

\section{How to cite this article:}

Ajeet Singh, Vinay Mohan Pathak and Navneet. 2016. Screening of Antimicrobial Potential of Barleria prionitis Linn Aerial Parts against Common Respiratory Tract Pathogens. Int.J.Curr.Microbiol.App.Sci. 5(7): 542-549. doi: http://dx.doi.org/10.20546/ijcmas.2016.507.059 